\title{
A process for the treatment of olive mill waste waters by immobilized cells
}

\author{
By A. Amhajji ${ }^{1}$, M. Faid ${ }^{2 \star}$ and M. ElYachioui ${ }^{1}$ \\ ${ }^{1}$ Faculté des Sciences BP 133 Kénitra, Morocco \\ ${ }^{2}$ Hassan II Institute of Agronomy and Veterinary Medicine. \\ BP 6202. Rabat-Instituts, Morocco.
}

\section{RESUMEN}

Proceso para el tratamiento de aguas residuales de molino de aceituna mediante células inmovilizadas.

Cepas de moho fueron inmovilizadas sobre serrín de madera como material sólido para el tratamiento de aguas residuales de un molino de aceituna (OMW). Los ensayos se realizaron en matraces. El proceso de tratamiento se monitorizó mediante determinaciones físico-químicas incluyendo $\mathrm{pH}$, polifenoles y $\mathrm{DQO}$, que también se analizaron durante el tiempo de incubación. En paralelo, la actividad inhibidora química de las OMW se confirma biológicamente mediante su efecto sobre algunos microorganismos incluyendo levaduras y bactérias ácido lácticas. Los resultados indicaron que los polifenoles se degradan hasta un nivel del $87 \%$. La DQO se redujo también al $60 \%$. El pH del efluente aumentó de 4.5 a 6.6. Los perfiles microbiológicos mostraron un mejor crecimiento a medida que avanzaba el tratamiento indicando una supresión de las actividades inhibidoras de las aguas (OMW). El comportamiento del crecimiento de todos los grupos de microorganismos fue similar y puede alcanzar altos niveles en el efluente.

PALABRAS-CLAVE: Aceituna - Agua residual - DQO - Moho - Polifenol - Serrín - Tratamiento.

\section{SUMMARY}

A process for the treatment of olive mill waste waters by immobilized cells.

Mould strains were immobilized on sawdust from woods as a solid material for the treatment of Olive Mill Waste (OMW) waters. Assays were carried out in flasks. The treatment process was monitored by physico-chemical determinations including $\mathrm{pH}$, polyphenols and COD, which were followed up during the incubation time. In parallel the chemical inhibitory activity of OMW was confirmed biologically by the determination of some microorganisms in the medium including the plate count, yeasts and lactic acid bacteria. Results indicated that the polyphenol degradation level was $87 \%$. The COD was also reduced by $60 \%$. The $\mathrm{pH}$ of the effluent increased from 4.5 to 6.6. The microbial profiles showed their best growth during the treatment period indicating a removal of the inhibitory activities from the OMW waters. The growth patterns of all microorganism groups were similar and could reach high levels in the effluent.

KEY-WORDS: Moulds - Olive - Polyphenols - Sawdust Treatment - Wastewater

\section{INTRODUCTION}

Polyphenols in the olive mill waste waters were investigated by several authors (Borja-Padilla et al, 1991; Maestro-Duran et al, 1991; Mouncif et al, 1995; Hamdi et al, 1992; Borja-Padilla et al, 1992a,b). All the studies focused on the reduction of polyphenols in OMW waters as a first step and then another system could be applied to complete the treatment. In a previous work (Amhajji et al, 2000), the yield of polyphenols reduction was improved by using agar as a solid material for the cell immobilization. This could not be done on a high scale and may not be easy to handle. The immobilized cell system may require strict conditions for convenient practices in a high scale plant for the treatment of OMW waters. It would be assumed that moulds and yeasts are the most active microorganisms in polyphenol hydrolysis and all the investigations concerning any biological system for the OMW water treatment may use these microorganisms.

The most commonly investigated strains in the field of OMW waters treatment were Aspergillus niger (Hamdi et al, 1992) Candida sp (Mouncif et al, 1995) Geotrichum candidum (Borja-Padilla et al, 1992ab) and the white olive mould (Amhajji et al, 2000). Other strains were also used such as $A$. terreus (Martinez-Nieto et al, 1992) to remove polyphenols from OMW waters for the biomethanization process. In the same way, Rannalli (1991) investigated various combined yeast strains in an aerobic treatment system of OMW waters. These microorganisms were used directly or with different systems including shaked cultures and submerged cells etc.. The choice of solid material to be used in the immobilization of microorganisms would be the most important point in the system. The use of an inert solid system would be practical and should lead to an industrial scale application. The yield in polyphenol reduction may depend on the efficiency of the solid material used in the immobilization.

In the present work, the removal process of polyphenols and the COD reduction was greatly improved by the use of mould strains immobilization on sawdust from woods.

\section{MATERIALS AND METHODS}

\subsection{Assays in flasks}

$10 \mathrm{~g}$ of sawdust were introduced into $250 \mathrm{~mL}$ erlenmeyer flasks. $5 \mathrm{~mL}$ of yeast extract glucose broth (Merk, Germany) were poured on sawdust and 
well mixed to have all the sawdust wet with the medium. The flasks were then autoclaved at $120^{\circ} \mathrm{C}$ for 20 minutes, allowed to cool to $30^{\circ} \mathrm{C}$ and inoculated with a pure culture on Potato Dextrose Agar (PDA) slants. The incubation was done at $30^{\circ} \mathrm{C}$ until a heavy culture developed in the flasks. $100 \mathrm{~mL}$ of OMW water were then poured into the flasks, which were placed on a shaker (Type IKA, Germany) at $30^{\circ} \mathrm{C}$

\subsection{Polyphenol determinations}

Total polyphenols were determined by the method described by Maestro-Duran et al (1991). A calibration curve was established in the same conditions using tannic acid as standard at concentrations of $0,1,2,2.4,3.6,4.8,6$ and 7.2 ppm. The absorbance (OD) at $725 \mathrm{~nm}$ was measured in a spectrophotometer against a blank containing $0 \mathrm{~mL}$ of tannic acid.

The COD was determined by the method described by APHA standards for examination of water and waste waters (APHA, 1989).

\subsection{Microbiological determinations}

Ten $\mathrm{mL}$ of the sample were diluted in sterile $90 \mathrm{ml}$ of peptone water $(0.1 \%)$ to prepare the initial dilution $(1 / 10)$.

\section{PC: Plate Count}

Appropriate serial dilutions (up to $10^{-6}$ ) of the sample in distilled water were pour plated on standard plate count agar (PCA) (Difco Laboratory, USA). The plates were incubated at $30^{\circ} \mathrm{C}$ for 48 hours.

\section{Lactic acid bacteria counts}

Lactic acid bacteria were pour plated on MRS agar (DeMan, Rogosa and Sharpe) (Merck, Germany). Plates were incubated at $30^{\circ} \mathrm{C}$ for 48 hours.

\section{Yeast counts}

Yeasts were directly plated on PDA (Potato Dextrose Agar) (Biokar, France). The medium was acidified to $\mathrm{pH} 3.5$ with sterile lactic acid (Merck, Germany). The plates were incubated at $30^{\circ} \mathrm{C}$ for 48 to 72 hours.

\section{RESULTS AND DISCUSSION}

\subsection{Physico-chemical}

The use of a solid material for immobilizing the culture in the treatment system was studied in order to improve the biological processes for the treatment of olive mill waste waters. The activity of the immobilized mould strains was confirmed by the rate of the polyphenoldegradation. Results reported in Figure 1 showed the effect of the mould strains on the removal of polyphenolic compounds from OMW waters. The initial concentration of polyphenols in the OMW waters was $3.2 \mathrm{~g} / \mathrm{L}$ which had been decreased to $0.42 \mathrm{~g} / \mathrm{L}$ for the assay with $100 \mathrm{~mL}$. This may correspond to a reduction rate of $87 \%$. The highest reduction yield of polyphenols was reached after 15 days . In a previous work (Amhajji et al, 2000), the authors reported a high level yield reduction of polyphenols using agar as solid material for the immobilization of moulds. In the present study, the yield is still high compared to the previous works and the same efficiency was found with sawdust which is a suitable solid material for handling and using in high scale treatment systems.

The high level of polyphenols in OMW waters especially those generated by the traditional processes would make these effluents hard to treat by the traditional processes because of the high inhibition activity of these compounds which may stop the microbial activity. According to Maestro-Duran et al (1991), the concentration of polyphenols may vary in the range of 6 to $17.5 \mathrm{~g} / \mathrm{l}$ in some Spanish OMW waters. In Morocco, Mouncif et al, (1993) reported a concentration of $64 \mathrm{~g} / \mathrm{L}$. Hamdi et al (1993) reported concentrations between 20 and $67.6 \mathrm{~g} / \mathrm{l}$ in Tunisian OMW waters. In the present study we found a concentration of $25 \mathrm{~g} / \mathrm{L}$ and this variation could be due to the traditional system for olive processing. The main problem to solve in OMW waters is the removal of polyphenols or at least a reduction to around a concentration under the lethal concentration which may inhibit microorganisms and then a biological process can be applied for the treatment of these effluents.

The removal of polyphenolic compounds was investigated in a previous work (Mouncif et al, 1995)

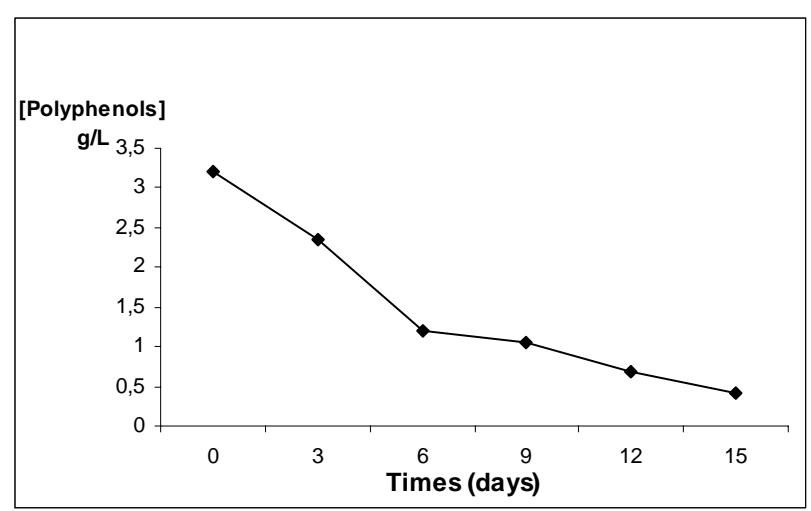

Figure 1

Polyphenol decrease pattern in olive mill waste waters by the immobilized culture. 
by the use of yeast strains isolated from the OMW waters. The authors found a relatively high reduction yield by yeasts in aerobic cultures. These conditions would not solve the problem since the OMW waters were diluted and the reduction was estimated to around $54 \%$ with more solids in the medium due to the yeast growth. Not only had the process given a low yield in polyphenol reduction, but the time to reach these results was also long.

COD was decreased from an initial concentration of $15.7 \mathrm{gO}_{2} / \mathrm{L}$ to $9 \mathrm{gO}_{2} / \mathrm{L}$ (Figure 2). The rate decrease for the COD was relatively low and the attained level is still high compared to the reduction of polyphenols but, even the COD reduction was low, the efficiency of the process is normally aimed to remove polyphenols first and the COD can be lowered in a second phase for completing the treatment.

The decrease of the COD would be related to the microbial activities in the effluent which could be stopped or delayed by the high concentrations of polyphenols in the crude OMW waters as well as a low $\mathrm{pH}$ and a high chloride concentration. These factors may act together against the microbial growth and the COD decrease may not reach low levels.

The reduction of COD is less important than the polyphenols at a premium. The removal of the polyphenols from OMW waters would be the most relevant phenomenon to study. This may lead to a non toxic waste for microorganisms and the biological system can be applied in the treatment of these effluents.

According to data reported by Mouncif et al (1993), OMW waters are highly contaminated with polyphenols $(64.7 \mathrm{~g} / \mathrm{l})$ which may inhibit the microbiota during aerobic and/or anaerobic treatment as was stated by the same authors.

The bioconversion of polyphenols is not directly related to the growth of the strains used. The immobilization of the culture on sawdust would require a heavy inoculation and may have a long lag phase in order to grow. Polyphenol biodegradation can be

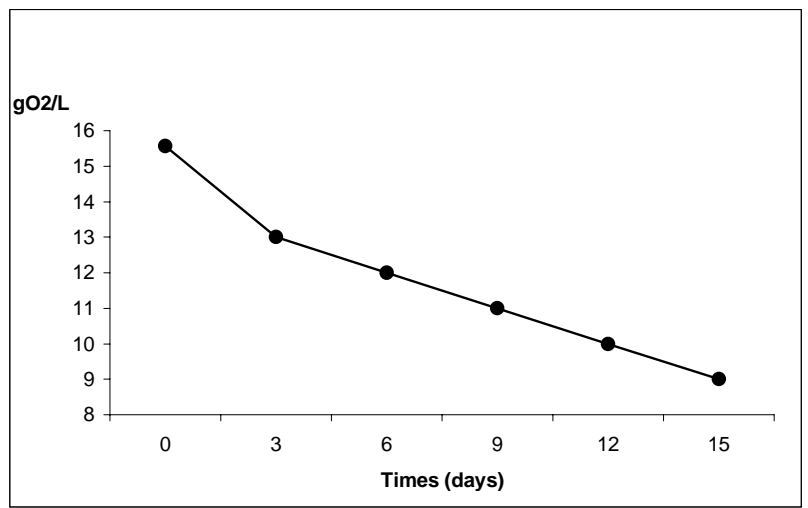

Figure 2

COD reduction by the immobilized culture in olive mill waste waters treatment assays. improved by looking deep into the growth conditions of the strains used in the present investigation.

The low $\mathrm{pH}$ of the OMW waters may also be involved in the growth inhibition of the microbiota that would act on COD reduction and facilitate the biological treatment of the effluent. The $\mathrm{pH}$ increased during the treatment period from 4.5 to 6.4 (Figure 3). The $\mathrm{pH}$ increase is unexpected and may not find a tangible explanation. The level of the $\mathrm{pH}$ reached at the end of the process (6.6) was still low for the microbial growth.

The removal of polyphenols in the OMW waters was investigated using Geotrichum candidum (Borja Padilla et al (1992a), Aspergillus terreus (Martinez-Nieto et al, 1992), A. niger (Hamdi et al, 1992), combined yeats strains (Rannalli, 1991), Candida sp (Mouncif et al, 1995) and moulds (Amhajji et al, 2000). High scale investigations are also being carried out and in the present work we demonstrated the cell immobilization system as a possible system and the efficiency of mould strains in OMW waters treatment and valorization.

\subsection{Microbiological}

The removal of polyphenols was also studied biologically for testing the removal of the inhibitory activity. The microbial profiles including plate counts, yeasts and lactic acid bacteria in the treatment systems showed a normal growth indicating the removal of the inhibiting activity in the medium (Figure 4). The growth pattern of the microorganisms in the medium as shown on the growth curves during the treatment period could tell about a concentration decrease of the inhibiting compounds in OMW waters.

The presence of yeasts and lactic acid bacteria in the OMW waters may suggest that they would be the most resistant to the polyphenols. The increase of the plate counts in the medium during the process, would also indicate a potent reduction in the polyphenol level in the OMW waters which are

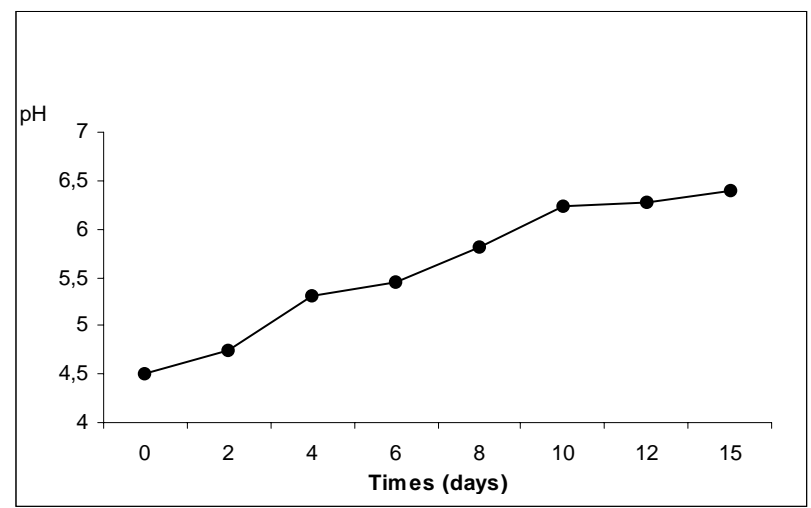

Figure 3

$\mathrm{pH}$ decrease during the treatment of olive mill waste waters with immobilized culture. 


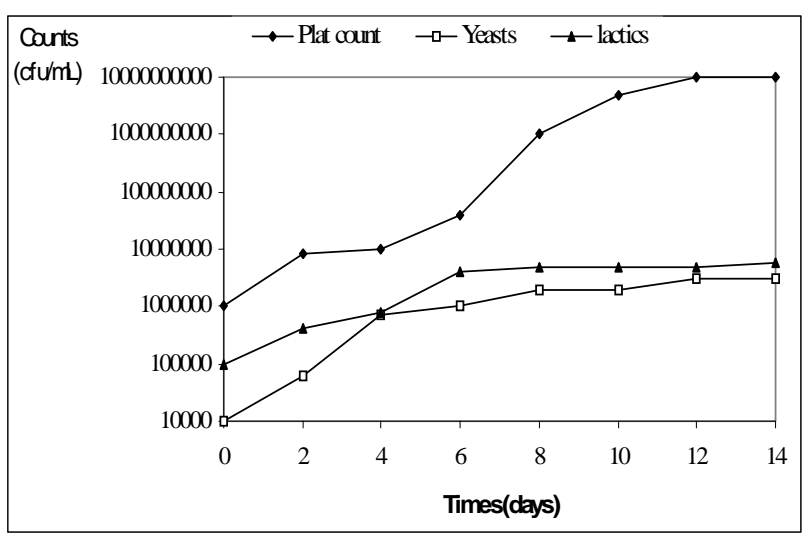

Figure 4

Microbial count profiles during the treatment of olive mill waste waters by the immobilized culture.

responsible for the inhibition. The plate count would group all the ubiquitous microorganisms that would grow on normal media but they are sensitive to the inhibitors as could be seen from the initial numbers.

Lactic acid bacteria and yeasts are the main microorganisms which can resist high polyphenol concentrations and they also represent the microbiota of OMW waters as was stated by Mouncif et al, (1993) because of the acidity and the high salt concentration. These are the reasons why we used these microorganisms to study the biological aspect of OMW waters. It would also be interesting to study the behavior of other microorganisms after eliminating the polyphenols and the $\mathrm{pH}$ establishment.

Donosa-Arce (1979) described some valorizations of OMW waters including single cell protein production by yeasts but the high concentration in polyphenols may inhibit the growth as well as the coloration of the obtained biomass.

Selected strains were also used by Florenzano and Balloni. (1983), Maestro et al. (1991), Hamdi et al. (1992), Martinez et al. (1992), Borja et al. (1994), and Mouncif et al. (1995) for the degradation of the polyphenols and the reduction of the COD.

\section{CONCLUSION}

The OMW waters generated by olive oil processing units are usually discarded in pits situated beside the unit, but it could also be discarded in natural water steams. This situation may raise the concentration of organic material and inhibitors, which would render the waste water hard to treat.

The strong reduction of polyphenols by the immobilized cultures of moulds on sawdust may undergo some conditions to be studied for a high scale process. This should be defined with more specifications as a procedure for the polyphenol removal from OMW waters. Moreover, the use of a suitable solid material for the immobilization may require certain conditions. In our case sawdust was the only solid material that would give acceptable results in immobilizing microorganisms.

\section{REFERENCES}

A. Amhajji, M.H. El-Jalil, M. Faid, J. L. Vasel and M. El-Yachioui (2000). Polyphenol removal from olive mill wastewaters by selected mould strains.51(6), 400-404.

APHA (American Public Health Association). (1989). Standard Methods for Examination of Water and Waste Water. (19th ed) APHA Pub Washington Dc.

Borja, P. R.; Alba, M. J. and Hidalgo, C. F. (1994). Digestion anaerobia de las agua de lavado de aceitunas de almazara: Influencia del período de recolección sobre la cinética del proceso. Grasas y Aceites, 45, 126-128.

Borja-Padilla, R., Martin-Martin, A., Maestro-Duran, R., Mendoza J. and Fiestas-Ros-De-Ursinos. (1991). Cinética del processo de depuración anaerobia de alpechín previante biotratado via aerobia. Grasas y Aceites, 42, 194-201.

Borja-Padilla, R., Martin-Martin, A. and Duran Barrantes, M.M. (1992 a). Estudio cinético del proceso de biometanizacion de alpechin de almazara clásica. previamente sometido a tratamiento aerobico con Geotrichum candidum. Grasas y Aceites, 43, 82- 86.

Borja-Padilla, R., Martin, A., Maestro, R., Alba, J. and Fiestas, J.A. (1992 b). Enhancement of the anaerobic digestion of olive mill waste water by removal of phenolic compounds inhibitors. Process Biochemistry, 27, 231-237

Donosa-Arce, L. (1979). Utilisation des sous-products dérivés de l'olive avec alternatives de consommation humaine et animale. Olivae, 19, 24-26.

Florenzano, G. and Balloni, W. (1983). Trattamento e utilizazione delle acque di scarico di oleificio: considerazioni analitiche e proposte tecnologiche. Genio rurale, 9.

Hamdi, M., Garcia, J.L. and Ellouz, R. (1992). Integrated biological process for olive mill wastewater treatment. Bioprocess Engineering, 8, 79 - 84.

Hamdi, M. (1993). Future prospects and constraints of olive mill waste waters use and treatment. A review. Bioprocess bioengineering, 8, 209-214.

Maestro Duran, R., Borja-Padilla, R., Martin-Martin, A., Fiestas-Ros-de-Ursinos, and ACHA-Mendoza. (1991). Biodegradacion de los fenolicos presentes en el alpechin. Grasas y Aceites, 42, 271-276.

Martinez-Nieto, L., Ramos Cormenzana, A., Garcia-Pareja, M.P. and Garido Hoyos, S.E. (1992). Biodegradacion de compuestos fenolicos del al pechin con Aspergillus terreus. Grasa y Aceites, 43, 75-81.

Mouncif, M., Tamoh, S., Faid, M. and Achkari-Begdouri, A. (1993). Physico-Chemical characteristics and the microbiota of Olive Mill Waste wasters. Grasas y Aceites, 44, 335-338.

Mouncif, M., Faid, M. and Achkari-Begdouri, A. and Lhadi, K. (1995). Biological valorization and treatment of olive mill waste waters by selected yeast strains. Grasas y Aceites, 46 (6) 344-348.

Ranalli, A. (1991). L'effluent des huiles d'olives: Proposition en vue de son utilisation et de son epuration. Réferences aux normes italiennes en la matière. 1ère Partie. Olivae, 37, 30-39. 